\title{
Instagram Influencer Analysis for Top 5 Categories in Turkey
}

\author{
Busra ERTOGRUL, Bogazici University, Management Information Systems, \\ busra.ertogrul@gmail.com, (DD 0000-0002-7428-6174 \\ Gizem KILICSIZ, Bogazici University, Management Information Systems, \\ gizem.kilicsiz@gmail.com, (D) 0000-0002-0307-8650
}

Aysun BOZANTA, Ryerson University, Data Science Lab, Dr., aysun.bozanta@ryerson.ca, 0000-0002-1768-6278

ABSTRACT

Keywords : : Instagram, Influencer, Engagement Rate, Social Media, Pearson Correlation
Social media platforms have become an inevitable part of our daily lives. Companies that noticed the intense use of social media platforms started to use them as a marketing tool. Even ordinary people have become famous by social media and companies have been sending their products to them to try and advertise. Many people have gained a considerable amount of money in this way and today new jobs are emerged like "Youtuber" and "Instagram Influencer". Therefore, ordinary people realized the power of social media and many people started to strength their digital identity over social media. The question raising in people's mind is that "What is the difference between the influencers and the ordinary people who have also digital identity over social media?". This study examined Instagram influencers for five categories namely fashion, makeup, photography, travel, and fitness in Turkey. As an exploratory study, the relationship between the influencers' average number of posts, the number of likes, the number of views, the number of comments, number of followers, and the number of following were examined. As well as the engagement rates of the followers to the influencers were calculated. In addition, the words they mostly used in the captions of the posts were examined.

\section{Türkiye'deki İlk 5 Kategori için Instagram Fenomenleri Analizi}

$\ddot{O Z Z}$

Sosyal medya platformları günlük hayatımızın kaçınılmaz bir parçası haline geldi. Sosyal medya platformlarının yoğun kullanıldı̆̆ını fark eden şirketler, bunları bir pazarlama aracı olarak kullanmaya başlad. Sıradan insanlar bile sosyal medya sayesinde unlu olmaya başladılar ve şirketler denemeleri ve reklamların yapmalar için ürünlerini bu kişilere ücretsiz olarak göndermeye başladılar. Birçok insan bu yolla önemli miktarda para kazanmakta ve bugün "Youtuber" ve "Instagram Influencer" gibi yeni işler ortaya çıkmaktadır. Bu nedenle sıradan insanlar sosyal medyanın gücünü anladılar ve birçok kişi dijital kimliğini sosyal medya üzerinden güçlendirmeye başladı. Bununla birlikte, insanların aklındaki soru, "Fenomenler ile sosyal medya üzerinde dijital kimliği olan sıradan insanlar arasındaki fark nedir?". Bu çalışma, Türkiye'de moda, makyaj, fotoğrafçılık, seyahat ve fitness olmak üzere beş kategoride Instagram fenomenlerini inceledi. Bir keşif çalışması olarak, fenomenlerin ortalama gönderi sayısı, beğenilerin sayısı, görüşlerin sayısı, 
yorumların sayısı, takipçi sayısı ve takip edenlerin sayısı arasındaki ilişki incelenmiştir. Takipçilerin, fenomenlere bağlılık oranları hesaplandı. Ek olarak, fenomenlerin biyografilerinde, Instagram hesaplarndaki tam isimlerinde ve gönderilerinde yazdıkları başlıklarda en çok kullandıkları kelimeler incelendi.

Anahtar : : Instagram, Fenomen, Pearson Correlation, Bağlılık Oranı, Sosyal Medya

\section{Kelimeler}

\section{INTRODUCTION}

As the communication technology has involved into the life, new social media platforms started to be very popular among people because they give a possibility to people playing an active role online and they enable people to create online content. One example of these social media platform is Instagram, which enables its users to take, upload and share their photos and stories, communicate with their friends online and like their photos and start a live video (Ewers, 2017).

Instagram provides people to be the witness of the daily lives of both celebrities and also ordinary people. By this way, some people, who create more and interesting content, have more and more followers day by day. Therefore, this situation leads to the occurrence of influencers. Influencers try to increase the number of their followers by sending posts almost every day, and in this way, they stay active and become a higher-level influencer. It is mentioned that the influencers are the people having lots of information about a certain topic such as a category of products, and their followers take their pieces of advice seriously (Tuten \& Solomon, 2013). These influencers also known as opinion leaders, put their time and energy not just for enjoying but also affecting people's opinions, behaviors, and attitudes. As time goes by, these efforts will return as the number of followers (Tuten \& Solomon, 2013). They have strong effects on people's lifestyles such as behaviors, dressing styles, places to go etc. If a normal person does the same thing also can be an influencer. They should be a part of communities and send posts regularly and should have more than 1000 followers (Effect, 2017). As they fulfil the requirements, they may start to influence people.

Instagram has reached more than 1 billion users in 2018 by increasing the number of users by 5 times in 4 years (Clement, 2019). It becomes the third mostly used social media platform all around the world according to the number of monthly active users (Kallas, 2018). Turkey is one of the countries, in which Instagram has been heavily used. There are 38 million Instagram users, which makes Turkey as the fifth country all around the world according to the number of Instagram users (Clement, 2019). In addition, 52236 Instagram influencers in Turkey have more than 1000 followers (Effects, 2017). These influencers have been mostly sharing their content in the categories of fashion, makeup, photography, travel, and fitness (Levin, 2017). 
This study examined Instagram influencers' data to gain insight into the behaviors of influencers and the engagement rate of their followers in these 5 categories. For this purpose, the average number of posts that influencers share to affect their followers and the words, they use most in captions, as well as the response of the followers by subscribing the influencer with their number of likes, the number of views and the number of comments and lastly the engagement rate are examined. The contribution of this study can be summarized as follows:

- $\quad 302$ Instagram influencers in 5 categories (makeup/beauty, travel, photography, fitness, and fashion/lifestyle) were examined. Although there are various studies in the literature mentioning Instagram influencers, they were not examined such a number of influencers in these categories separately.

- The behaviors of Instagram influencers were examined both quantitatively (correlation analysis and text mining) and qualitatively (interview technique).

- In addition, the engagement rates were calculated for each category to understand the loyalty of the followers towards influencers.

\section{LITERATURE REVIEW}

Individuals who have a wide reach on their Instagram accounts are started to be used by companies as influencers (Ewers, 2017). Companies started to do this because many people trust these influencers since people feel close to them and see them joe public. According to Woods (2016), these influencers are able to make some advertisement, even though their followers might be aware of the fact that they get paid. In addition to this, Amos, Holmes, and Strutton (2008) found that the effect of an influencer depends on her/his attributes. That is, according to whether an influencer's attitude is correct to their followers, s/he can affect their followers. Especially the credibility of the influencer seems to be of significance when it comes to the effectiveness of an advertisement (Ohanian, 1990). Djafarova and Rushworth (2017) summarize the findings of several researchers who found that influencers were seen as more reliable than celebrities. Forbes (2016), as well, emphasizes that influencers have a normal life like public compared to celebrities so they have more effect on people.

In addition, influencers can be able to affect their followers' buying behaviors as it is mentioned that they are individuals who have the power to affect their followers' thanks to their authority, knowledge, position, or relationship with their followers (Businessdictionary.com-Influencers, n.d.). In addition to this, the Finnish Influencer marketing company "PING Helsinki" defines influencers as those who share their opinions on social media platforms because they have their own community in social media and they have the willingness to produce sponsored contents for their followers (Pinghelsinki.fi, n.d.), so they can easily influence their followers' buying behaviors. 
Influencers have some areas that they specialize such as makeup, fashion, travelling, photography, and fitness. Because of their skills, today many consumers give importance to the thoughts of the influencers on Instagram before they buy a product (Yurttaş, 2010). In Finland, according to a study that is done about influencer marketing, it was found that $66 \%$ of 15-24-year-olds remembered the promotions that they see on Instagram and $63 \%$ of them found this information flow to be beneficial (Veissi, 2017). The remaining $72 \%$ were found to be very useful and $42 \%$ were found to be useful. Also, in this study, it was found that when marketing in cooperation with Instagram influencers with a 33\% increase, a positive growth rate of $33 \%$ was also affected by sales. In this study, it was observed that $35 \%$ of the accounts that belong to the most preferred Instagram influencers were related to music, 30\% of humor, $29 \%$ of animals, $28 \%$ of sports, $39 \%$ of the participants clothing, $32 \%$ of cosmetics and beauty products, $25 \%$ of electronics and $23 \%$ of jewelry so people are impressing by these accounts on Instagram before people buy products (Veissi, 2017).

As it is mentioned above, because influencers affect their followers' buying behaviors, companies realized the importance of influencer marketing so they started to interact with the influencers. However, they should not work with every influencer for their marketing strategies, they need to find the right influencer for their companies. Therefore, when they try to identify the right influencer for their companies, it is important to know that influencer has to be related to the products or service line and s/he should appeal to the segment being targeted (Brown \& Hayes, 2008). In addition to this, when choosing the right influencers for a company, there are certain qualities that the influencers should have according to PING Helsinki. they should be an expert and opinion leader in his/her field, have the right target audience for the company, know how to produce suitable content, like stories, videos, pictures, and social media posts, understand marketing and have a sufficient number of committed followers in the relevant social media channels, have good communication skills and understand the value of their work (Pinghelsinki.fi, 2017).

\section{METHODOLOGY}

\section{DATA COLLECTION}

The total number of influencers in Turkey is 52236 and they have several followers more than $1 \mathrm{k}$ and $6 \mathrm{~m}$ (Levin, 2017). The average number of followers of these influencers is 18986 and they have 7\% engagement rate (Levin, 2017). The key metric for analyzing the influencers from Turkey, the engagement level was chosen (Levin, 2017). Winning on Instagram requires regularly analyzing results, and at this point measuring your engagement rate is the best option.

If the person wants to influence his/her followers via Instagram, he/she should expect an engagement rate of more than $6 \%$ and it brings much bigger opportunities (Laurence, 2018). 
The influencers in Turkey are splatted up into 28 categories. These are; handicraft, brand, parenting, travel, tattoo artist, wedding, animal, business, food photography, pastry, fitness, fashion-lifestyle, makeup-beauty, modeling, entrepreneur, photography, luxury lifestyle, interior design, real estate, celebrity, dancer, sport, surf, motorsport, DJ, Youtuber and College (Levin, 2017).

Among these categories, top 5 categories, which are presented in Table 1, were chosen as the categories with the highest engagement rates to be examined.

Table 1. Number of influencers, the average number of followers and engagement rates

\begin{tabular}{llll}
\hline Category & $\begin{array}{l}\text { Number of } \\
\text { Influencers }\end{array}$ & $\begin{array}{l}\text { Average Number of } \\
\text { Followers }\end{array}$ & $\begin{array}{l}\text { Average Engagement } \\
\text { Rate }\end{array}$ \\
\hline Photography & 9117 & 12879 & $8 \%$ \\
Travel & 7343 & 13993 & $8 \%$ \\
Makeup/Beauty & 3739 & 19548 & $7 \%$ \\
Fitness & 3304 & 16912 & $7 \%$ \\
Fashion/Lifestyle & 8731 & 18499 & $6 \%$ \\
\hline
\end{tabular}

In Table 1, the "Category" column describes the most popular 5 categories as it is mentioned. The "Number of Influencers" column describes the number of influencers that each category has. The "Average Number of Followers" column represents the number of followers that the influencers have by category. The last column which is "Average Engagement Rate" shows the average engagement rate between influencers and followers by category. As it is shown the most popular category is Photography with 9117 influencers, although this category has the lowest average number of followers, the engagement rate is the highest at $8 \%$. It is followed by Travel with 7343 influencers having $8 \%$ engagement rate. The third ones are Makeup/Beauty and Fitness. Makeup/Beauty has 3739 influencers, and Fitness has 3304 influencers with the 7\% engagement rate. The last one is Fashion/Lifestyle with 8731 influencers, 18499 average number of followers and the lowest engagement rate $6 \%$.

To examine the relationship between the influencers' average number of posts and the number of likes, the number of views, the number of comments, $1 \%$ of influencers in each category were collected. The data was pulled by web scraping in PHP language. Instagram API could not be used for this study because security rules are so strict, and it does not allow to gather the necessary data. Instagram API could not be used for this study because security rules are so strict, and it does not allow to gather the necessary data. 
Table 2. The number of Influencers for correlation analysis

\begin{tabular}{ll}
\hline Category & Number of influencers \\
\hline Makeup/Beauty & 37 \\
Photography & 91 \\
Fashion/Lifestyle & 87 \\
Fitness & 33 \\
Travel & 73 \\
\hline Total & 302 \\
\hline
\end{tabular}

Following features of each influencer were collected:

- ID,

- username,

- full name,

- biography,

- number of followers,

- number of people they follow,

- $\quad$ profile image link,

- $\quad$ post count, and

- $\quad$ category of the influencer.

To collect the posts of each influencer, $0.1 \%$ of total influencers were chosen and all data about their every post was collected. Table 3 presents the number of influencers in each category and the total number of posts of them. Total of 13553 posts shared by a total of 32 influencers was examined (Table 3). Each post includes:

- Username,

- $\quad$ shortcode,

- $\quad$ created time,

- type,

- $\quad$ image link,

- $\quad$ caption,

- $\quad$ number of video views, 
- number of likes,

- $\quad$ number of comments, and

- $\quad$ modified time.

Table 3. The number of Influencers for text mining

\begin{tabular}{lll}
\hline Category & Number of influencers & Number of Posts \\
\hline Makeup/Beauty & 4 & 1020 \\
Photography & 9 & 6993 \\
Fashion/Lifestyle & 9 & 1036 \\
Fitness & 3 & 1369 \\
Travel & 7 & 3135 \\
\hline Total & 32 & 13553 \\
\hline
\end{tabular}

\section{DATA PREPROCESSING}

The following changes were applied before starting the analysis:

- Some users' information was incorrect because they might change their username or completely close the account. That's why these types of entries completely erased to reach consistent and fully reliable data.

- Some user IDs have been duplicated because of an inconsistency in the account. That's why it is also removed.

20 lines from the list of users have been removed.

\section{DATA ANALYSIS}

\section{Descriptive Analysis}

Descriptive statistics of the variables the number of total posts, daily posts, followers and following are summarized according to each category in the following tables. Table 4 presents descriptive statistics of the number of total posts. The highest mean value belongs to the fashion category, which is followed by fitness, make up, travel, and photography categories.

Table 4. Descriptive Statistics of the number of total posts

\begin{tabular}{lllll}
\hline & Mean & Standard Deviation & Min & Max \\
\hline Fashion & 3492 & 4320 & 50 & 31364 \\
Photography & 1105 & 1451 & 27 & 7464 \\
Makeup & 1357 & 1089 & 41 & 3976 \\
Fitness & 1614 & 2623 & 62 & 12505 \\
\hline
\end{tabular}




$\begin{array}{lllll}\text { Travel } & 1223 & 1279 & 86 & 6882\end{array}$

Table 5 presents descriptive statistics of the number of daily posts. The highest mean value is belonged to the fashion category again, which is followed by make-up, fitness, travel, and photography categories. The reason for the intense sharing of accounts in the fashion category may be their online sales.

Table 5. Descriptive Statistics of the number of daily posts

\begin{tabular}{lllll}
\hline & Mean & Standard Deviation & Min & Max \\
\hline Fashion & 27 & 64 & -47 & 294 \\
Photography & 0.29 & 3 & -25 & 3 \\
Makeup & 13 & 28 & $-0,6$ & 111 \\
Fitness & 0.94 & 1,5 & $-0,2$ & 6,7 \\
Travel & 0.57 & 0,6 & $-0,4$ & 2,8 \\
\hline
\end{tabular}

Table 6 presents descriptive statistics of the number of followers. The highest mean value belongs to the make-up category, which is followed by fitness, fashion, travel and photography categories.

Table 6. Descriptive Statistics of the number of followers

\begin{tabular}{lllll}
\hline & Mean & Standard Deviation & Min & Max \\
\hline Fashion & 142692 & 262525 & 1284 & 1787484 \\
Photography & 95290 & 268687 & 1110 & 1630588 \\
Makeup & 221799 & 570594 & 1558 & 3327628 \\
Fitness & 173324 & 418536 & 5083 & 2279598 \\
Travel & 116636 & 255137 & 2302 & 1564968 \\
\hline
\end{tabular}

Table 7 presents descriptive statistics of the number of following. The highest mean value belongs to the photography category, which is followed by fashion, travel, fitness and make up categories.

Table 7. Descriptive Statistics of the number of following

\begin{tabular}{lllll}
\hline & Mean & Standard Deviation & Min & Max \\
\hline Fashion & 1621 & 1851 & 1 & 7473 \\
Photography & 2185 & 2365 & 15 & 7505 \\
Makeup & 1140 & 1466 & 2 & 7337 \\
Fitness & 1211 & 1614 & 34 & 6790 \\
Travel & 1597 & 2013 & 3 & 7494 \\
\hline
\end{tabular}


As it is mentioned in Table 3 the detailed post information of the influencers is collected for varying number of influencers from each category. Following table shows the average number of video views (ANOVV), the average number of likes (ANOL), the average number of comments (ANOC), the number of followers (NOF), and the engagement rate for each influencer from five categories (Table 8). The engagement rate is calculated by the following formula:

$$
\text { Engagement Rate }=(\mathrm{AVL}+\mathrm{AVC}) / \mathrm{NOF}
$$

Table 8. Detailed Statistics of the Influencers and Their Posts

\begin{tabular}{|c|c|c|c|c|c|}
\hline 0 & AVV & ANOL & ANOC & $\mathrm{NOF}$ & Engagement Rate \\
\hline Fash_Inf_1 & 9215 & 1546 & 37 & 21427 & 7,39 \\
\hline Fash_Inf_2 & 175851 & 4977 & 80 & 168109 & 3,01 \\
\hline Fash_Inf_3 & 136 & 133 & 4 & 3295 & 4,16 \\
\hline Fash_Inf_4 & 6437 & 56 & 0,88 & 1950 & 2,92 \\
\hline Fash_Inf_5 & 0 & 189 & 7 & 7829 & 2,50 \\
\hline Fash_Inf_6 & 268 & 148 & 2 & 19871 & 0,75 \\
\hline Fash_Inf_7 & 249 & 310 & 2 & 21378 & 1,46 \\
\hline Fash_Inf_8 & 0 & 21 & 0,2 & 2288 & 0,93 \\
\hline Fash_Inf_9 & 0 & 32 & 3 & 2013 & 1,74 \\
\hline Make_Inf_1 & 2307 & 36 & 0,45 & 57881 & 0,06 \\
\hline Make_Inf_2 & 1371 & 190 & 5 & 2405 & 8,11 \\
\hline Make_Inf_3 & 291 & 225 & 20 & 1558 & 15,73 \\
\hline Make_Inf_4 & 99 & 10 & 1 & 14933 & 0,07 \\
\hline Trav_Inf_1 & 499 & 195 & 6 & 4566 & 4,40 \\
\hline Trav_Inf_2 & 481 & 127 & 4 & 3958 & 3,31 \\
\hline Trav_Inf_3 & 4052 & 300 & 16 & 11192 & 2,82 \\
\hline Trav_Inf_4 & 161 & 176 & 5 & 2302 & 7,86 \\
\hline Trav_Inf_5 & 297 & 192 & 5 & 4469 & 4,41 \\
\hline Trav_Inf_6 & 0 & 176 & 1 & 9998 & 1,77 \\
\hline Trav_Inf_7 & 4301 & 499 & 9 & 19382 & 2,62 \\
\hline Photo_Inf_1 & 1665 & 1101 & 22 & 12969 & 8,66 \\
\hline Photo_Inf_2 & 924 & 500 & 5 & 6463 & 7,81 \\
\hline Photo_Inf_3 & 3047 & 616 & 4 & 20675 & 3,00 \\
\hline Photo_Inf_4 & 538 & 324 & 6 & 7998 & 4,13 \\
\hline Photo_Inf_5 & 1123 & 1272 & 27 & 9238 & 14,06 \\
\hline Photo_Inf_6 & 72 & 401 & 0,64 & 6161 & 6,52 \\
\hline Photo_Inf_7 & 0 & 364 & 4 & 33974 & 1,08 \\
\hline Photo_Inf_8 & 0 & 2048 & 0,5 & 20340 & 10,07 \\
\hline Photo_Inf_9 & 4222 & 147 & 2 & 7955 & 1,87 \\
\hline Fit_Inf_1 & 58149 & 5573 & 175 & 118324 & 4,86 \\
\hline Fit_Inf_2 & 6143 & 355 & 9 & 9594 & 3,79 \\
\hline Fit_Inf_3 & 4593 & 267 & 5 & 6890 & 3,95 \\
\hline
\end{tabular}




\section{Correlation Analysis}

The correlation analysis is performed to find whether there are any correlations between the variables; the number of followers, the number of daily posts, the average number of likes, comments of posts and the average number of video views and lastly the number of following of influencers. The result of the correlation analysis is presented in Table 9.

Table 9. The Result of Correlation Analysis

\begin{tabular}{lllllll}
\hline & Following & Followers & Daily post & Like & Comment & View \\
\hline Following & 1 &,- 216 &,- 032 &, 277 &,- 164 &,- 115 \\
Followers & $-0,216$ & 1 & 0,053 & 0,035 & $0,769^{* *}$ & $0,681^{* *}$ \\
Daily post & $-0,032$ & 0,053 & 1 & $-0,073$ & 0,089 & 0,101 \\
Like & 0,277 & 0,035 & $-0,073$ & 1 & 0,056 & 0,058 \\
Comment & $-0,164$ & $0,769^{* *}$ & 0,089 & 0,056 & 1 & $0,618^{* *}$ \\
View & $-0,115$ & $0,681^{* *}$ & 0,101 & 0,058 & $0,618^{* *}$ & 1 \\
\hline
\end{tabular}

** p-value is less than 0.01.

It can be observed from Table 9 that there is a strong positive correlation $(\mathrm{r}=0,769$, sig. $=0,000$ ) between the number of followers and the number of comments. In addition, there is a moderate correlation between the number of followers and the number of views $(\mathrm{r}=0,681$, sig. $=0,000)$, and the number of views and comments $(r=0,618$, sig. $=0,000)$. There is no significant correlation among other variables.

\section{Text Analysis}

Text analysis is applied to Influencers' biographies, full names, and the captions of their posts to determine the most frequently used words. By this way, it can be examined the words they are using the most on the captions to gain more followers and how many times they use their category name in the biography section. In Table 10, the most frequent words in influencers' biography and full name with their frequencies and percentages. Frequency column shows the number of occurrences in the text, and the percentage gives the rate of this word according to the whole text. It is important to gain insight into the importance of words that influencers use. 
Table 10. The most frequent words in influencers' biographies and full names

\begin{tabular}{llll}
\hline Category & The Most Frequent Words & Frequency & Percentage \\
\hline \multirow{4}{*}{ Fashion } & Fashion & 23 & 1,65 \\
& Moda (Turkish word means fashion) & 14 & 1 \\
& Blogger & 12 & 0,86 \\
& Lifestyle & 12 & 0,86 \\
& Dm & 11 & 0,79 \\
\hline \multirow{4}{*}{ Fitness } & Fitness & 8 & 1,84 \\
& Trainer & 5 & 1,02 \\
& Founder & 4 & 0,81 \\
& Personal & 4 & 0,81 \\
& Beslenme (Turkish word means nutrition) & 4 & 0,81 \\
\hline \multirow{3}{*}{ Photography } & Fotoğraf (Turkish word means photograph) & 12 & 0,85 \\
& Photographer & 9 & 0,64 \\
& Mutlu (Turkish word means happy) & 5 & 0,35 \\
& Dm & 4 & 0,28 \\
& Foto (Turkish word means photo) & 4 & 0,28 \\
\hline \multirow{5}{*}{ Travel } & Makyaj (Turkish word means make-up) & 19 & 3,85 \\
& Makeup & 9 & 1,57 \\
& Dm & 9 & 1,57 \\
& Profesyonel (Turkish word means professional) & 5 & 0,87 \\
& Reklam (Turkish word means advertisement) & 4 & 0,7 \\
\hline & Travel & 15 & 1,3 \\
& Seyahat (Turkish word means to travel) & 9 & 0,78 \\
& Blog & 7 & 0,6 \\
& Gezgin (Turkish word means traveller) & 7 & 0,6 \\
& & 6 & 0,52 \\
\hline
\end{tabular}

In Table 10, 301 influencers are examined, 66 influencers from the travel category, 82 from fashion/lifestyle, 29 from fitness, 88 from photography, and 36 from makeup/beauty. In Table 10, for fashion/lifestyle category, the most frequent words are as same as the category name which is fashion. The interesting ones are Blogger and DM (direct message). It means most of the fashion/lifestyle influencers write also some blogs and they give importance to DM messages for the feedback or questions. Fitness also has the most frequent word as its category name. Here, the interesting points are "Founders", "Personal" and "Beslenme" (Nutrition). "Founder" means some of them have their own fitness saloons or they found something for fitness. "Personal" and "Nutrition" mean they give personal training to their followers and they prepare a personal nutrition list and maybe diet lists. In the photography section, the interesting thing is "Mutlu" (Happy). The reason may those followers like to see something with the caption "Happy". For the makeup/beauty category, the most interesting word is 
"Reklam" (Advertisement). It shows makeup influencers make advertisement most. For the travel also, the interesting point is "Blog" which means most of the travel influencers write also blogs.

Table 11. The most frequent words in influencers' captions of posts

\begin{tabular}{|c|c|c|c|}
\hline Category & The Most Frequent Words & Frequency & Percentage \\
\hline & Reklam & 123 & 0,73 \\
\hline & Moda & 89 & 0,52 \\
\hline & Sevdiğim & 55 & 0,32 \\
\hline \multirow[t]{5}{*}{ Fashion } & Blog'da & 46 & 0,27 \\
\hline & Elbise & 28 & 0,16 \\
\hline & \#Fitness & 28 & 0,89 \\
\hline & \#Fitnessblender & 12 & 0,38 \\
\hline & \#Aesthetic & 12 & 0,38 \\
\hline \multirow[t]{5}{*}{ Fitness } & Uzaktan & 11 & 0,35 \\
\hline & \#Turtleshellabs & 10 & 0,32 \\
\hline & \#Photography & 136 & 1,78 \\
\hline & \#Photooftheday & 30 & 1,7 \\
\hline & \#Photo & 126 & 1,65 \\
\hline \multirow[t]{5}{*}{ Photography } & \#Photoshoot & 123 & 1,61 \\
\hline & \#Modelphotography & 120 & 1,57 \\
\hline & Yaraticilik & 103 & 2,81 \\
\hline & \#Makyaj & 58 & 1,4 \\
\hline & \#Instadaily & 58 & 1,4 \\
\hline \multirow[t]{5}{*}{ Makeup } & \#Makeup & 58 & 1,4 \\
\hline & \#Likeforlike & 58 & 1,4 \\
\hline & \#Foto & 382 & 1,46 \\
\hline & \#Photographer & 347 & 1,33 \\
\hline & \#Photo & 340 & 1,3 \\
\hline \multirow[t]{2}{*}{ Travel } & Olmak & 335 & 1,28 \\
\hline & Burada & 332 & 1,27 \\
\hline
\end{tabular}

In Table 11, there are 10403 data examined. 2322 of them came from the fashion category with 9 influencers, 1307 came from fitness category with 3 influencers, 2599 came from photography category with 9 influencers, 1126 from makeup/beauty category with 4 influencers, and 3049 came from travel category with 7 influencers.

In Table 11, for the fashion category, the interesting words are Reklam (Advertisement) and Blog. The result is parallel with the biographies. They advertise and write blogs. Influencers from fitness, they use general hashtags and "Uzaktan" (From a distance), means they provide support from a distance. For photography, they also use lots of hashtags in their captions. For the makeup category, the most frequent one is interesting which is "Yaratıcilı" (creativity). It shows the makeup should be creative, different from others. For the travel, 
influencers generally use hashtags about photography. It shows that a traveller should have photos with nice views not only from different places but also with aesthetic views. The other interesting things are "Olmak" (To Be) and "Burada" (Here) means a question like "Who wants to be here?", it encourages followers to write comments and tag friends, in this way they can gain more followers.

\section{CONCLUSION}

Nowadays, influencer marketing is highly popular. So, there is a question regarding who is the influencer and how do companies succeed in influencer marketing?. The current study aims to answer these tough questions.

First, the accounts of the people that are labelled as an influencer were retrieved. Since the collected data cannot cover entire regions, a specific region has been determined to achieve more accurate results. This region is Turkey in the current study. Next, people who have more than 1000 followers are labelled as an influencer as suggested by the extant literature and their categories are then determined. Lastly, the total number of influencers from each category was equally distributed to the number of influencers, and a total of 302 data were collected randomly.

The findings suggest that there is a positive correlation between the average number of comments, the average number of video views and the number of followers. Also, one of the findings clearly shows which words should be used and focused more frequently by influencers on their biography and caption. On the contrary to what was hypothesized, there is no correlation. It may indicate that sending comments on the post of an influencer and the number of views on videos should be more valuable than the number of likes of that post.

This study has helped the companies to use influencers for advertising more effectively. As a result of the study, it was found that companies should pay attention rather to the number of comments of influencers and the number of video views, than the number of likes of posts.

The scope of this study covers only Turkey, but larger areas can be included to reach global information about influencers. Thus, more general data can be obtained by collecting and analyzing more international influencers and cross-regional comparisons can be made, or global firms can use fewer numbers of influencers. Due to security policies of Instagram, only a limited amount of data could be analyzed. The accuracy can be improved by increasing the number of data instances. In this study, influencers were discussed. So different actors such as followers may be further added to study. For example, the questions that are closely related to demographic characteristics, (i.e. which age range follows whom?) may be critical to 
understanding the phenomenon. In this way, companies can better target customers by cooperating with influencers.

\section{REFERENCES}

Amos, C., Holmes, G., \& Strutton, D. (2008). Exploring the relationship between celebrity endorser effects and advertising effectiveness: A quantitative synthesis of effect size. International Journal of Advertising, 27 (2), 209-234.

$\begin{array}{llll}\text { Business } & \text { dictionary, } & \text { Retrieved }\end{array}$ http://www.businessdictionary.com/definition/influencers.html

Brown, D. \& Hayes, N. (2008). Influencer Marketing: Who really influences your customers? Routledge.

Clement, J. (2019). Leading countries based on number of Instagram users as of July 2019 (in millions). Retrieved from https://www.statista.com/statistics/578364/countries-with-most-instagramusers/

Dijilopedi (2018), 2018 Türkiye İnternet Kullanım ve Sosyal Medya İstatistikleri, Retrieved from https://dijilopedi.com/2018-turkiye-internet-kullanim-ve-sosyal-medya-istatistikleri/

Djafarova, E. \& Rushworth, C. (2017). Exploring the credibility of online celebrities' Instagram profiles in influencing the purchase decisions of young female users. Computers in Human Behavior, 68, $1-7$.

Effect. (2017). Yeni Pazarlama Yaklaşımı; Influencer Marketing (Fenomen Pazarlamasl), Retrieved from http://www.effect.com.tr/yeni-pazarlama-yaklasimiinfluencer-marketing-fenomenpazarlamasi/

Ewers, N. L. (2017) \#sponsored -Influencer Marketing on Instagram - An Analysis of the Effects of Sponsorship Disclosure, Product Placement, Type of Influencer and their Interplay on Consumer Responses. Master Thesis, University of Twente.

Forbes, K. (2016). Examining the Beauty Industry's Use of Social Influencers. ELON JOURNAL, 78.

Laurence, Christy. How To Calculate Your Engagement Rate on Instagram, Retrieved From www.plannthat.com/calculate-engagement-rate-on-instagram/?

Instagram.com, Why Instagram, Retrieved from https://business.instagram.com/getting-started/ Accessed: 18.12.2018

Kallas, P. (2018). Top 15 Most Popular Social Networking Sites and Apps. Retrieved From https://www.dreamgrow.com/top-15-most-popular-social-networking-sites/

Levin, A. (2017). The 2019 State of Influencer Marketing Report, Retrieved from https://www.relatable.me/the-state-of-influencer-marketing-2019

Ohanian, R. (1990). Construction and validation of a scale to measure celebrity endorsers' perceived expertise, trustworthiness, and attractiveness. Journal of advertising, 19 (3), 39-52. 
Pinghelsinki, Mitä on vaikuttaja markkinointi, Retrieved from http://pinghelsinki.fi/artikkeli/mita-onvaikuttajamarkkinointi/ Accessed: 18.12.2018

Tuten, T. L. \& Solomon, M. R. (2013). Social media marketing. International ed. Pearson Education. Upper Saddle River, New Jersey.

Veissi, I. (2017). Influencer Marketing on Instagram (Bachelor's Thesis). Haaga- Helia Universty of Applied Sciences. s. 1.

Woods, S. (2016). \#Sponsored: The Emergence of Influencer Marketing. The University of Tennessee. Honors Thesis Projects. Retrieved from http://trace.tennessee.edu/utk_chanhonoproj/1976

Yurttaş, Ö. U. (2010). Blog'ların Marklar Üzerindeki Gücü. İstanbul Aydın Üniversitesi Dergisi, 2 (8), 107122. 